\title{
Publisher Correction: C9orf72 arginine-rich dipeptide repeats inhibit UPF1-mediated RNA decay via translational repression
}

\author{
Yu Sun, Aziz Eshov, Jeffrey Zhou, Atagun U. Isiktas [D \& Junjie U. Guo (1)
}

Correction to: Nature Communications https://doi.org/10.1038/s41467-020-17129-0, published online 3 July 2020.

The original version of this article contained errors in Figs. 2A, 3A and 3B that were inadvertently introduced during typesetting. The third sample of Fig $2 \mathrm{~A}$, the third panel of Fig 3A, and the third sample of Fig 3B were inadvertently labelled $\left(\mathrm{G}_{4} \mathrm{C}_{2}\right)_{100}$ RNA rather than $\left(\mathrm{G}_{2} \mathrm{C}_{4}\right)_{100}$ RNA. In addition, the fifth sample of Fig $2 \mathrm{~A}$ were inadvertently labelled $\mathrm{GA}_{50}$-GFP and rather than $\mathrm{GR}_{50}$-GFP. These errors have now been corrected in both the PDF and HTML versions of the article.

Published online: 06 January 2022

Open Access This article is licensed under a Creative Commons Attribution 4.0 International License, which permits use, sharing, adaptation, distribution and reproduction in any medium or format, as long as you give appropriate credit to the original author(s) and the source, provide a link to the Creative Commons license,
and indicate if changes were made. The images or other third party material in this article are included in the article's Creative Commons license, unless indicated otherwise in a credit line to the material. If material is not included in the article's Creative Commons license and your intended use is not permitted by statutory regulation or exceeds the permitted use, you will need to obtain permission directly from the copyright holder. To view a copy of this license, visit http://creativecommons.org/licenses/by/4.0/.

(c) The Author(s) 2022 